\title{
Understanding variability in greenhouse gas emission estimates of smallholder dairy farms in Indonesia
}

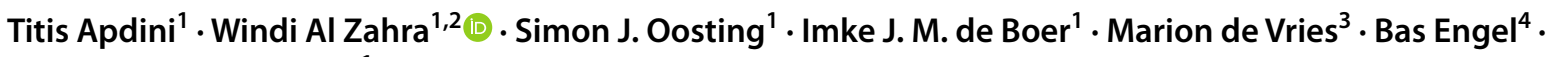 \\ Corina E. van Middelaar ${ }^{1}$
}

Received: 15 December 2020 / Accepted: 3 May 2021 / Published online: 1 June 2021

(c) The Author(s) 2021

\begin{abstract}
Purpose Life cycle assessment studies on smallholder farms in tropical regions generally use data that is collected at one moment in time, which could hamper assessment of the exact situation. We assessed seasonal differences in greenhouse gas emissions (GHGEs) from Indonesian dairy farms by means of longitudinal observations and evaluated the implications of number of farm visits on the variance of the estimated GHGE per kg milk (GHGEI) for a single farm, and the population mean.

Methods An LCA study was done on 32 smallholder dairy farms in the Lembang district area, West Java, Indonesia. Farm visits (FVs) were performed every 2 months throughout 1 year: FV1-FV3 (rainy season) and FV4-FV6 (dry season). GHGEs were assessed for all processes up to the farm-gate, including upstream processes (production and transportation of feed, fertiliser, fuel and electricity) and on-farm processes (keeping animals, manure management and forage cultivation). We compared means of GHGE per unit of fat-and-protein-corrected milk (FPCM) produced in the rainy and the dry season. We evaluated the implication of number of farm visits on the variance of the estimated GHGEI, and on the variance of GHGE from different processes.

Results and discussion GHGEI was higher in the rainy $\left(1.32 \mathrm{~kg} \mathrm{CO}_{2}\right.$-eq kg$\left.{ }^{-1} \mathrm{FPCM}\right)$ than in the dry $\left(0.91 \mathrm{~kg} \mathrm{CO}_{2}\right.$-eq kg $\mathrm{kg}^{-1}$ FPCM) season $(P<0.05)$. The between farm variance was $0.025 \mathrm{~kg} \mathrm{CO}_{2}$-eq kg ${ }^{-1} \mathrm{FPCM}$ in both seasons. The within farm variance in the estimate for the single farm mean decreased from 0.69 (1 visit) to 0.027 (26 visits) $\mathrm{kg} \mathrm{CO}_{2}$-eq kg ${ }^{-1}$ FPCM (rainy season), and from 0.32 to $0.012 \mathrm{~kg} \mathrm{CO}_{2}$-eq kg${ }^{-1} \mathrm{FPCM}$ (dry season). The within farm variance in the estimate for the population mean was 0.02 (rainy) and 0.01 (dry) $\mathrm{kg} \mathrm{CO}_{2}$-eq kg ${ }^{-1} \mathrm{FPCM}$ (1 visit), and decreased with an increase in farm visits. Forage cultivation was the main source of between farm variance, enteric fermentation the main source of within farm variance.

Conclusions The estimated GHGEI was significantly higher in the rainy than in the dry season. The main contribution to variability in GHGEI is due to variation between observations from visits to the same farm. This source of variability can be reduced by increasing the number of visits per farm. Estimates for variation within and between farms enable a more informed decision about the data collection procedure.
\end{abstract}

Keywords Life cycle assessment · Longitudinal approach · Greenhouse gas emissions · Seasonal observation · Smallholder dairy farms $\cdot$ Indonesia

\section{Introduction}

Communicated by Brad G. Ridoutt.

Titis Apdini and Windi Al Zahra have contributed equally as first authors to the manuscript.

Windi Al Zahra

windi.alzahra@wur.nl; windialzahra@apps.ipb.ac.id

Extended author information available on the last page of the article
The consumption of dairy products in Indonesia is rising due to population growth, a growing middle class and dietary shifts (Priyanti and Soedjana 2015). However, the national milk production only fulfils $17 \%$ of the national demand of dairy product (BPS 2018). The Indonesian government policy aims to fill this gap between production and demand by, among others, increasing the number 
of dairy cattle on smallholder dairy farms (from 2-3 to 7 heads per farm) (Kemenko Ekon 2016). Policies targeted at smallholder farms may have significant effects on national milk production because $88 \%$ of national milk production originates from these farms (Morey 2011).

Depending on Indonesia's strategy taken to increase domestic milk production, greenhouse gas emissions (GHGE) from dairy production may further increase, particularly if the numbers of cattle are to be increased (Tubiello et al. 2014; De Vries et al. 2019). Life cycle assessment (LCA) is a well-known method to assess GHGE along the production chain of milk and is mainly used to identify emission hotspots and potential mitigation options. In the calculation of GHGE from dairy farms, three main sources are identified: enteric fermentation (major GHG: methane $\left(\mathrm{CH}_{4}\right)$ ), manure management (major GHGs: nitrous oxide $\left(\mathrm{N}_{2} \mathrm{O}\right)$ and $\left.\mathrm{CH}_{4}\right)$, and feed production including cultivation, processing and transportation (major GHGs: carbon dioxide $\left(\mathrm{CO}_{2}\right)$ and $\mathrm{N}_{2} \mathrm{O}$ ) (FAO and GDP 2018). Feed is a major contributor to global estimates of GHGE from dairy production because it is associated with $\mathrm{CH}_{4}$ emission from enteric fermentation (47\% of total GHGE) and emissions related to feed production (19\%) (Gerber et al. 2013). Manure management is another important contributor, accounting for $26 \%$ of total emissions in the global dairy chain (Gerber et al. 2013).

Most LCA studies on smallholder farms in tropical regions use data that is collected at one particular moment in time (i.e. cross-sectional observation) to estimate the annual average of GHGE related to milk and live weight production (e.g. Garg et al. 2016; Taufiq et al. 2016). The main reason for this is that data collection is difficult and time consuming. To address variation in farm management practices over time, researchers often ask farmers to recall the situation over a particular year or season (e.g. De Vries et al. 2019). However, both cross-sectional observations and farmer recall could hamper an accurate assessment of the exact situation on a farm. For example, a study by Migose et al. (2020) showed that assessment of milk yield based on farmers recall was less accurate than those based on recordings, while milk yield explains a significant part of the variation in GHG emission intensity (e.g. De Vries et al. 2019; Wilkes et al. 2020). As the climate of Indonesia is characterised by a dry and a rainy season, dairy farmers adapt their practices to these seasons, mainly with regard to the amount and type of feed offered to dairy cattle (De Vries and Wouters 2017). In addition, dairy farmers in other tropical countries also adapt their manure management practices across seasons (Zake et al. 2010; Paul et al. 2009). Seasonal differences in management practices and in the quantity and quality of available feed (Lanyasunya et al. 2006; Maleko et al. 2018; Richard et al. 2015) can be an important source of variability of GHGE estimates of smallholder dairy farms in the tropics.
To address the variation in farm management practices over time in the assessment of GHGE, longitudinal observations are preferred over a single observation. As frequent sampling from smallholder farms in tropical countries is time-consuming and costly, however, the number of visits (observations) per farm required for accurate estimation of GHGE should be optimised. To decide on the number of visits per farm, insight into the relation between the visits per farm and the variation in the estimated GHGE per kg milk is required. This study, therefore, aimed to assess seasonal differences in GHGE per kg milk of Indonesian dairy farms by means of longitudinal observations, and subsequently evaluate the implications of the number of visits per farm on the variation of the estimated GHGE per kg milk for a single farm, and for the population mean (as estimated by the mean over several farms).

\section{Methods}

\subsection{Study area and farm selection}

The LCA study was done in the Lembang district area, West Java, Indonesia. This area is the second largest dairy production region in Indonesia and provides $14 \%$ of the total national milk supply (Kementan 2018; KPSBU 2018). The area is an equatorial zone according to the Köppen-Geiger climate classification, with an average daily temperature above $18{ }^{\circ} \mathrm{C}$, a rainy season from October to March (monthly precipitation $>60 \mathrm{~mm}$ ) and a dry season from April to September (monthly precipitation $<60 \mathrm{~mm}$ ).

We selected 32 dairy farms from 300 randomly selected smallholder dairy farms surveyed by De Vries and Wouters (2017). To address variation in farm management that is likely to affect GHGE, we assigned these 300 farms to one of four feeding systems according to land size and milk yield, and to four manure management systems (MMSs). Because land size and milk yield, and consequently the feeding systems of the selected farms were not the same as recorded by De Vries and Wouters (2017) upon our farm visit, categorisation based on feeding system was dismissed. The four MMSs were as follows: apply manure for forage cultivation, sell manure, use manure for bio-digester (which could subsequently be used as fertiliser), and discharge manure. The classification of MMSs was based on the main part of faeces being collected. If farmers collected manure, they only collected faeces and discharged urine. Initially, we selected 8 farms randomly within each MMS, but some farms changed their MMS in between the study of De Vries and Wouters (2017) and our farm visits; hence, we allocated them to a different MMS. Consequently, the number of farms differed between MMSs. Throughout the period of data 
collection all farmers stuck to the MMS they practiced at the start of the farm visits.

\subsection{System description}

Figure 1 provides an outline of the dairy farming system and all activities included in our LCA. The system boundary of our LCA includes upstream and on-farm activities. The upstream activities include the production (cultivation and processing) and transportation of the inputs to the farms. The inputs are purchased feeds (concentrate, tofu by-product, cassava pomace and rice straw), inorganic fertiliser (urea) used for forage cultivation, fuel and electricity. On-farm activities include management of the dairy herd (lactating cows, dry cows, heifers, female and male calves and male cattle), manure management and forage cultivation. The outputs from the dairy farms are milk, live animals and sold manure. Most of the produced milk $(95 \%)$ is sold to the dairy cooperative in the Lembang district, whereas the remainder is consumed by households or fed to calves. Farmers sell cattle occasionally to the slaughterhouses or other farmers. Crop cultivation for human consumption and households is excluded from our system boundary as these processes are considered not to be part of the dairy production system. The utilisation of biogas to replace liquid petroleum gas (LPG) at the household is included within the system boundary of this study.

\subsection{Data collection}

We visited each of the 32 smallholder dairy farms every two months from December 2017 to October 2018. The farm visits (FVs) from December 2017 to April 2018 (FV1 to FV3) were considered visits in the rainy season, whereas the FVs from June to October 2018 (FV4 to FV6) were considered visits in the dry season.

During each FV, we assessed feed intake of the cows, daily milk yield and cattle body weight. To assess daily feed intake of the cows, we measured the offered feed and subtracted the feed refusal collected on the following day. To calculate the milk yield, we weighed the milk yield at morning and afternoon milking time. We also weighed the amount of milk fed to calves. The milk output from the farm was estimated as the total daily milk yield minus the amount of milk fed to calves. To estimate the cattle body weight, we measured the length and girth of the cows and used the Schoorl equation (Kusuma and Ngadiyono 2017).

We sampled forage and milk at each dairy farm once in the rainy season (at FV1) and once in the dry season (at FV5). Samples of tofu by-product and cassava pomace were collected only in the rainy season because these feeds are produced by food processing industries using standardised procedures and similar ingredients throughout the year, so we assumed that the variation of nutrient composition was minimal. In the case of concentrate, the dairy cooperative in Lembang district produced the concentrate for all dairy farms in the district and regularly analysed the nutritional composition of the concentrate. We observed that the nutritional composition of concentrate tested by

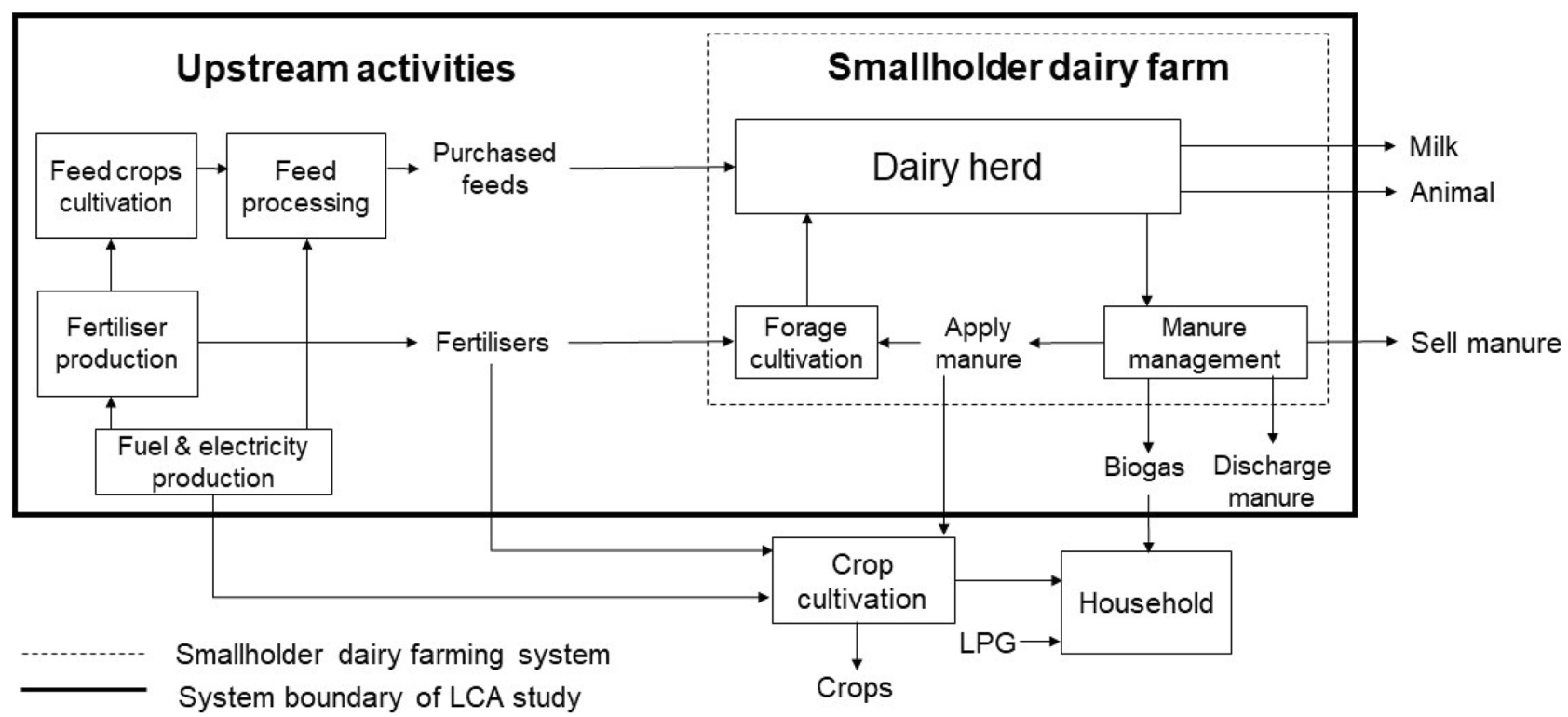

Fig. 1 Outline of the smallholder dairy farming system in the Lembang district, Indonesia, and all activities included in our system boundary 
the dairy cooperative showed minimal variation although the composition of ingredients varied slightly throughout the year. Hence, we analysed a concentrate sample only once in the rainy season. The proximate analysis was performed to assess the concentrations of dry matter, crude protein, crude fibre and crude fat of feed samples (AOAC 1990). A milk sample was collected from each lactating cow for analysis of protein and fat content. All laboratory analyses were performed at the laboratory of the Faculty of Animal Science, IPB University (Bogor Agricultural University), Indonesia.

At each FV, we asked the farmers about current herd composition, manure management, forage cultivation and price of purchased feeds. Regarding herd composition, we asked the number of animals present, the number of purchased and sold animals in the 2 months prior to the FV, and animals' age. In terms of manure management, we asked the farmers to estimate the proportion of faeces currently being collected, the proportion of faeces being used in the biodigester, the proportion of applied faeces on the forage cultivation area, the proportion of sold faeces and the proportion of manure being discharged (including urine). To gain insight into forage cultivation, we asked about land size, quantity of applied fertilisers, and period of fertilisation. In addition, we asked the farmers about the usage of LPG for cooking in the household to be able to calculate the amount of LPG used before and after installation of an anaerobic digester.

Only at one FV, we asked the farmers about the size of the bio-digester, and the origin of rice straw, tofu by-product, and cassava pomace. The origin of these products was used to calculate the distance of transportation to the farms, which we subsequently used to calculate the emission from transportation of purchased feed. We interviewed the staff members of the dairy cooperative in charge of concentrate production to collect information about variation in the composition of concentrate throughout the year, annual energy use for concentrate production and total annual production of concentrate.

\subsection{Calculation of emissions}

Emission factors from databases and information from literature were used to calculate GHGE from upstream activities. In case of purchased feeds, we used the LEAP database (FAO 2015) to estimate GHGE from cultivation of various feed crops (e.g. soybean, cassava, wheat, maize; see Table 1). In case of GHGE from rice straw, we also included $\mathrm{CH}_{4}$ emissions from rice fields (IPCC 2019). The emissions related to energy use to process and transport purchased feeds to the smallholder dairy farms were based on Ecoinvent Version 3 (Wernet et al. 2016). All assumptions to calculate emissions related to cultivation, transportation and processing of feed crops are provided in the supplementary material (Table S1). The GHGE from purchased feeds are presented in Table 1 and are all calculated based on economic allocation (see Sect. 2.5).

The $\mathrm{CH}_{4}$ emissions from on-farm activities included those from enteric fermentation and manure management (including the storage, application and discharge of manure and the production of biogas). For enteric fermentation, we used IPCC (2019) Tier 2 to estimate the conversion of gross energy intake into enteric $\mathrm{CH}_{4}$ emissions. The gross energy intake was calculated by multiplying feed intake and gross energy content of feed. The latter was estimated based on the concentration of carbohydrates, protein and fat in the collected feed samples (NRC 2001). To calculate $\mathrm{CH}_{4}$ emission from manure management, we multiplied the quantity of faeces being collected with the methane conversion factor (MCF) of different manure management systems (IPCC 2019). In the case of faeces stored for sale, the MCF of the IPCC-category liquid/slurry was used. In the case faeces

Table 1 Greenhouse gas emissions (GHGE) in $\mathrm{kg} \mathrm{CO}_{2}$ equivalent per $\mathrm{kg}$ of feed in dry matter

\begin{tabular}{lll}
\hline Feeds & Emission factor & Reference \\
\hline Wheat pollard & 0.26 & FAO (2015); personal communication with staff of Bogasari Flour Mill, Indonesia \\
Rice bran & 0.61 & Agatha (2016); IPCC (2019); Wernet et al. 2016 \\
Corn gluten feed & 0.37 & Vellinga et al. (2013) \\
Copra meal & 0.16 & Vellinga et al. (2013) \\
Palm kernel meal & 0.20 & Vellinga et al. (2013) \\
Coffee hull & 0.10 & Personal communication with coffee farmers in Lembang, Indonesia \\
Tofu by-product & 0.76 & FAO (2015); Liu et al. (2017); Wernet et al. (2016); Zannah (2017) \\
Cassava pomace & 0.24 & FAO (2015); Suroso (2011); Wernet et al. (2016) \\
Concentrate & $0.25-0.30 *$ & Wernet et al. (2016); personal communication with staff of dairy cooperative in \\
& & Lembang, Indonesia \\
Rice straw & 0.42 & Agatha (2016); IPCC (2019); Wernet et al. (2016)
\end{tabular}

*The emission factor of concentrate varies due to different composition and energy use in the feed mill throughout 1 year 
stored in the digester for biogas generation, MCF of the IPCC-category anaerobic digester was used. In the case faeces or digestate (the by-product of bio-digester) applied for forage cultivation, and in the case of faeces or digestate to be discharged, MCF of the IPCC-category daily spread was used. Emissions from the bio-digester also included biogas loss that is not used for cooking in households. Ideally, households use the biogas to reduce or fully replace LPG-use for cooking. In some cases, however, biogas yield outweighed LPG-use for cooking, or was not fully utilised, resulting in an additional loss of $\mathrm{CH}_{4}$. The biogas loss was calculated by subtracting the biogas used for cooking from the biogas yield, and assuming a $\mathrm{CH}_{4}$ content of $65 \%$ (IRENA 2016). The biogas used for cooking was calculated based on the difference between LPG use before and after installation of the bio-digester. The biogas yield was calculated based on IRENA (2016). The parameters of temperature and retention time (IRENA 2016), the volatile solid (IPCC 2019), and the volume of the digester, were used to calculate the biogas yield.

On-farm $\mathrm{N}_{2} \mathrm{O}$ emissions are attributed to manure management, and to urea application for forage cultivation. To calculate $\mathrm{N}_{2} \mathrm{O}$ emission from manure management, we first estimated the production of manure- $\mathrm{N}$ on farm. This was done by subtracting total $\mathrm{N}$ retained for milk, growth, and pregnancy from the total $\mathrm{N}$ intake. We calculated the total $\mathrm{N}$ intake from feed by multiplying the total daily feed intake of the cows on dry matter basis with the $\mathrm{N}$ content of the feed. To calculate $\mathrm{N}$ retention for lactating cows, we quantified $\mathrm{N}$ in milk by multiplying the total milk yield with the $\mathrm{N}$ content in milk. To calculate $\mathrm{N}$ retention for heifers, female and male calves, and male cattle ( $<24$ months old), we estimated the retained $\mathrm{N}$ for growth, and to calculate $\mathrm{N}$ retention for dry cows we estimated the retained $\mathrm{N}$ for pregnancy (on 190-279 days) based on NRC (2001). Since the faeces and urine are treated separately in smallholder dairy farms (i.e. $100 \%$ urine being discharged), the quantity of faecal $\mathrm{N}$ and urinary $\mathrm{N}$ were calculated separately as described by Zahra et al. (2020). The quantity of faecal-N was obtained by multiplying the proportion of faecal- $\mathrm{N}$ in the manure- $\mathrm{N}$ with the production of manure- $\mathrm{N}$. To calculate the quantity of faecal$\mathrm{N}$ collected, we multiplied the quantity of faecal $\mathrm{N}$ with the proportion of faeces collected. To calculate $\mathrm{N}_{2} \mathrm{O}$ emissions from manure management, we multiplied the quantity of faecal-N collected with the $\mathrm{N}_{2} \mathrm{O}$ emission factors of different manure management systems (IPCC 2019). To estimate direct $\mathrm{N}_{2} \mathrm{O}$ emissions from manure storage (i.e. for manure that is stored and being sold), the $\mathrm{N}_{2} \mathrm{O}$ emission factor of the IPCC-category liquid/slurry was used. To estimate direct $\mathrm{N}_{2} \mathrm{O}$ emissions from production of biogas, the $\mathrm{N}_{2} \mathrm{O}$ emission factor of the IPCC-category anaerobic digester was used. To estimate direct $\mathrm{N}_{2} \mathrm{O}$ emissions from applied faeces and applied digestate for forage cultivation, and to calculate direct $\mathrm{N}_{2} \mathrm{O}$ emissions from discharged faeces and discharged digestate, the $\mathrm{N}_{2} \mathrm{O}$ emission factor of the IPCC-category daily spread was used. To calculate direct $\mathrm{N}_{2} \mathrm{O}$ emissions from discharged urine, also the $\mathrm{N}_{2} \mathrm{O}$ emission factor of the IPCC-category daily spread was used.

Indirect $\mathrm{N}_{2} \mathrm{O}$ emissions are related to $\mathrm{N}$ losses in the form of $\mathrm{NH}_{3}, \mathrm{NO}_{\mathrm{x}}$ volatilisation and in the form of $\mathrm{NO}_{3}^{-}$leaching. To estimate volatilisation of $\mathrm{NH}_{3}$ and $\mathrm{NO}_{\mathrm{x}}$ from manure that is stored and sold, the emission factor of the IPCCcategory liquid/slurry was used. For production of biogas, the emission factor of the category anaerobic digester was used. For applied faeces and applied digestate for forage cultivation, and for discharged manure and discharged digestate, the emission factor of the daily spread was used. For discharged urine, also the emission factor of the category daily spread was used. The fraction of $\mathrm{N}$ losses in the form of $\mathrm{NO}_{3}{ }^{-}$leaching for specific manure management systems were based on personal communication with experts (De Vries et al. 2019). To estimate leaching of $\mathrm{NO}_{3}{ }^{-}$from manure storage, a leaching fraction of $18 \%$ was used. For applied faeces and applied digestate for forage cultivation, a $\mathrm{NO}_{3}{ }^{-}$leaching fraction of $30 \%$ was used. For discharged manure including discharged digestate, the $\mathrm{NO}_{3}{ }^{-}$leaching fraction was calculated by subtracting $\mathrm{N}$ losses in the form of $\mathrm{N}_{2} \mathrm{O}, \mathrm{NH}_{3}$ and $\mathrm{NO}_{\mathrm{x}}$, from the total amount of $\mathrm{N}$ excreted. The default emission factor of 0.01 for indirect $\mathrm{N}_{2} \mathrm{O}$ emissions from $\mathrm{N}$ volatilisation, and 0.0075 for indirect $\mathrm{N}_{2} \mathrm{O}$ emissions from $\mathrm{N}$ leaching and runoff was used (IPCC 2006). In addition, $\mathrm{CO}_{2}$ emissions related to urea application were included based on IPCC Tier 1 (IPCC 2006).

\subsection{Allocation methods}

Some of the processes along the production chain yield multiple outputs, such as rice cultivation yielding rice and straw, and dairy production yielding milk and meat. This study used different methods to deal with allocation of GHGE for such processes. To allocate emissions related to feed production economic allocation was used, which means that emissions from processes with multiple outputs were allocated to the outputs based on their relative economic value (Table S2, supplementary material).

To allocate GHGE to milk, we applied economic allocation with bimonthly data on body weight gain of the animals serving as an estimate for meat output. Prices of meat and milk were based on farm surveys and the body weight gain was calculated by the difference in body weight of individual animals (young stock and male cattle) between two sequent FVs. As another means to reduce data requirements, we explored the implications of using a method that prevents allocation by dividing the herd into milk and meat producing animals. This method seems justified because young stock and male cattle were generally sold to generate additional 
income, and not kept for replacement. In case of this alternative method, all GHGE from the adult cows (i.e. lactating and dry cows) are attributed to milk production, and all GHGE related to heifers, female and male calves, are attributed to meat production. The advantage of this method is that data requirements are reduced to a minimum (e.g. all data related to young stock, such as data on feed intake, manure production, and productivity, as well as economic data to calculate allocation factors can be discarded), being beneficial for studies in tropical regions that are often characterised by data scarcity and uncertainty. This method will be further referred to as system division.

In addition to milk and meat, some of the dairy farmers also sell manure (sold faeces) to crop farmers. We did not allocate any emissions to sold faeces, nor apply another method to account for this output for two reasons. First, the economic benefit from sold faeces is very low in comparison with milk and sold animals; applying economic allocation would not have changed the results and conclusions of this study. Second, although sold faeces is used by other farmers as organic fertiliser, it is not replacing synthetic fertiliser (personal communication with local crop farmers), which means that system substitution or system expansion does not apply here. In case of faeces that are used to produce biogas, however, system substitution was found to be most suitable as biogas replaces the use of LPG in farmer's households. Foregone emissions related to the production and combustion of this LPG were therefore subtracted from the total GHGE on those farms.

\subsection{Impact assessment and interpretation}

GHGE from different processes, from all farm visits, at the upstream (i.e. purchased feed and fertilisers) and on-farm (i.e. enteric fermentation, manure management and forage cultivation) processes were converted into $\mathrm{CO}_{2}$-equivalents $\left(\mathrm{CO}_{2}\right.$-eq) using the weighing factors 1 for $\mathrm{CO}_{2}, 265$ for $\mathrm{N}_{2} \mathrm{O}$ and 28 for biogenic $\mathrm{CH}_{4}$ (Myhre et al. 2013). Subsequently, GHGE from all processes (i.e. upstream and on-farm) were summed up into total GHGE. To calculate greenhouse gas emission intensity (GHGEI), we divided total GHGE by milk yield (Eq. 1).

GHGEI $=\frac{\sum \text { GHGE from different processes }}{\text { milk yield }}$

where $\sum$ GHGE from different processes are the total GHGE from enteric fermentation, manure management, forage cultivation, and purchased feed ( $\mathrm{kg} \mathrm{CO} 2$-eq), and milk yield is the milk output from a farm in kilogram of fat- and proteincorrected milk (kg FPCM) according to IDF (2015) (Eq. 2).

$\mathrm{FPCM}=$ measured milk yield $(\mathrm{kg}) \times[0.1226 \times$ milk fat $\%$

$$
+0.0776 \times \text { milk protein } \%+0.2534]
$$

\subsection{Statistical analysis}

Means of characteristics of the smallholder dairy farms in the rainy and the dry season were compared by the paired sample $t$-test. Means of GHGEI of the four different MMSs in the rainy and the dry season were compared using ANOVA. Means of GHGEI in the rainy and the dry season were also compared by the paired sample $t$-test. To understand the relation between the GHGEI based on economic allocation and GHGEI based on system division in both seasons, we did a Pearson correlation analysis.

For analysis of the data collected per farm and season, a linear mixed model was used. Initially, this model comprised five dispersion parameters: separate components of farms (between farms component of variance) and error (within farms component of variance) per season and a covariance between random effects of the same farm within the two seasons. A likelihood ratio test (Cox and Hinkley 1979), comparing this model with a reduced model with a single component of variance for farms and for error for both seasons showed heterogeneity of variance between seasons $(P$ value $=0.005)$. Estimated components of variance for farms in the two seasons were found to be virtually the same and a second likelihood ratio test comparing with a model with a common variance component for farms and different error components for seasons was not significant at all $(P$ value $=1.0$ ). Therefore, for the final calculations a linear mixed model was used with the same component of variance for farms in both seasons but different within farm variance in the two seasons. In addition, all linear mixed models considered comprised fixed effects for the two seasons, allowing for a difference in expected response between seasons. Components of variance were estimated by restricted maximum likelihood (REML, e.g. McCulloch et al. 2008). Facilities from $\mathrm{R}$ routine glmmTMB (Brooks et al. 2017) were used for the calculations, i.e. to obtain deviances to calculate the likelihood ratio tests.

The estimated components of variance per season allow for the evaluation of the following criteria to compare sampling schemes with 1,2 or 3 , and even more visits collected per farm. In addition to the sampling schemes with 1,2 or 3 visits we therefore also compared a hypothetical scheme with a number of 26 visits (weekly) collected per farm per season. Criteria considered were as follows: (1) expected width of a 0.95 confidence interval (CI) of the mean of a single farm :2 $21.96 \times \sqrt{\frac{\sigma_{\text {error }}^{2}}{n}} ;$ (2) expected width of a 0.95 confidence interval of the population mean based upon a number of randomly selected farms: $2 \times 1.96 \times \sqrt{\frac{\sigma_{\text {farm }}^{2}}{m}+\frac{\sigma_{\text {error }}^{2}}{n m}}$; (3) repeatability 
per farm, expressed as the correlation between (hypothetical) repeated farm means: $\sigma_{\text {farm }}^{2} /\left(\sigma_{\text {farm }}^{2}+\frac{\sigma_{\text {error }}^{2}}{n}\right)$, where $n$ is the number of visits per farm, e.g. $n=1,2$, or 3 , $m$ is the number of farms, and components of variance are replaced by their REML estimates. In all expressions, per season, the same estimated component of variance for farms (i.e. between farm variance) was used for both seasons, but different estimates for the error variances (i.e. within farm variance). To understand the importance of variation in GHGE from different processes, including enteric fermentation, manure management, purchased feed and forage cultivation the same procedure was followed.

\section{Results}

\subsection{Comparing GHGEI of milk between seasons}

Table 2 shows the characteristics of the farms in the rainy and the dry season based on all six FVs. The average herd size of the 32 farms was 4 adult cows. On average, the dry matter intake (DMI) of lactating cows was $15 \%$ lower in the dry season than in the rainy season. The DMI of heifers was $35 \%$ lower in the dry season than in the rainy season. The proportion of elephant grass in the ration for lactating cows was lower whereas the proportions of rice
Table 2 Characteristics of 32 smallholder dairy farms in Lembang district, Indonesia, in the rainy and the dry season, based on six farm visits from December 2017 to October 2018

\begin{tabular}{|c|c|c|}
\hline Characteristics & Rainy season* & Dry season* \\
\hline Farm size (ha) & $0.4(0.38)$ & $0.4(0.36)$ \\
\hline \multicolumn{3}{|l|}{ Herd composition (number per farm) } \\
\hline Adult cows (lactating and dry cows) & $4.2(2.1)$ & $3.8(1.9)$ \\
\hline Female calves and heifers & $1.5(1.8)$ & $1.8(1.8)$ \\
\hline Male cattle (6-24 months old) & $0.2(0.5)$ & $0.3(0.8)$ \\
\hline Male calves ( $\leq 6$ months old) & $0.6(1.2)$ & $0.8(1.5)$ \\
\hline \multicolumn{3}{|l|}{ Dry matter intake $\left(\mathrm{kg} \text { animal }^{-1} \text { day }^{-1}\right)^{\mathrm{c}}$} \\
\hline Lactating cows & $15.1^{\mathrm{a}}(3.4)$ & $13.1^{\mathrm{b}}(3.6)$ \\
\hline Dry cows & $10.9(3.9)$ & $10.0(4.5)$ \\
\hline Heifers (6-24 months old) & $10.6^{\mathrm{a}}(4.9)$ & $6.3^{\mathrm{b}}(3.5)$ \\
\hline Male cattle (12-24 months old $)^{\mathrm{d}}$ & $9.1(5.8)$ & $8.2(4.7)$ \\
\hline Male cattle (6-12 months old $)^{\mathrm{d}}$ & $4.4(2.6)$ & $3.5(2.7)$ \\
\hline \multicolumn{3}{|l|}{ Dietary proportion for lactating cows in dry matter } \\
\hline Roadside grass & $0.06(0.14)$ & $0.06(0.11)$ \\
\hline Elephant grass & $0.28^{\mathrm{a}}(0.18)$ & $0.19^{\mathrm{b}}(0.16)$ \\
\hline Rice straw & $0.09^{\mathrm{b}}(0.13)$ & $0.13^{\mathrm{a}}(0.14)$ \\
\hline Concentrate & $0.35^{\mathrm{b}}(0.15)$ & $0.39^{\mathrm{a}}(0.17)$ \\
\hline Tofu by-product & $0.13^{\mathrm{b}}(0.15)$ & $0.16^{\mathrm{a}}(0.18)$ \\
\hline Cassava pomace & $0.09(0.10)$ & $0.07(0.09)$ \\
\hline Crude protein intake $\left(\mathrm{g} \mathrm{cow}^{-1}\right.$ day $\left.^{-1}\right)$ & $136.0(18.0)$ & $137.0(16.7)$ \\
\hline Gross energy (GE) intake $\left(\mathrm{MJ} \mathrm{cow}^{-1} \mathrm{day}^{-1}\right)$ & $252.4^{\mathrm{a}}(44.2)$ & $214.8^{\mathrm{b}}(47.0)$ \\
\hline Metabolisable energy (ME) intake (MJ cow ${ }^{-1}$ day $\left.^{-1}\right)$ & $161.8^{\mathrm{a}}(22.6)$ & $143.3^{\mathrm{b}}(28.5)$ \\
\hline ME/GE (fraction) & $0.62^{\mathrm{b}}(0.05)$ & $0.63^{\mathrm{a}}(0.03)$ \\
\hline Estimate of GE intake based on IPCC (2019) $\left(\mathrm{MJ} \mathrm{cow}^{-1}\right.$ day $\left.^{-1}\right)$ & $320.3(37.7)$ & $319.6(43.5)$ \\
\hline Body weight of adult cow $(\mathrm{kg})$ & $450.9(34.9)$ & $462.7(37.8)$ \\
\hline Milk production $\left(\mathrm{kg} \mathrm{cow}^{-1} \mathrm{day}^{-1}\right)$ & $14.1(3.5)$ & $15.3(4.4)$ \\
\hline Milk fat content $(\%)$ & $4.0^{\mathrm{a}}(0.5)$ & $3.3^{\mathrm{b}}(0.6)$ \\
\hline Milk protein content $(\%)$ & $2.9^{\mathrm{b}}(0.2)$ & $3.6^{\mathrm{a}}(0.7)$ \\
\hline Inorganic fertiliser for forage cultivation $\left(\mathrm{kg} \mathrm{N}_{\text {farm }}{ }^{-1}\right)$ & $12.4^{\mathrm{a}}(7.7)$ & $0^{\mathrm{b}}$ \\
\hline Faeces application for forage cultivation $\left(\mathrm{kg} \mathrm{N}\right.$ farm $\left.^{-1}\right)$ & $9.3(29.4)$ & $4.1(10.4)$ \\
\hline Collected manure on farm ( $\%$ of faeces) & $69^{\mathrm{a}}(26)$ & $59^{\mathrm{b}}(35)$ \\
\hline
\end{tabular}

*Value between the brackets presents standard deviation $(n=32)$; superscripts show significant difference $(P$ value $<0.05)$

${ }^{\mathrm{c}}$ The DMI for calves ( $<6$ months old) was excluded because the farmers fed only milk

${ }^{\mathrm{d}}$ The DMI for male cattle was classified into two categories of age because high variation of the DMI if the data being presented in one category 
straw, concentrate, and tofu by-product were higher in the dry season than in the rainy season. The content of gross and metabolisable energy in diets for lactating cows during the dry season was lower than during the rainy season, but the protein content was similar in both seasons. The daily milk yield per cow did not differ between seasons. The amount of $\mathrm{N}$ applied via inorganic fertiliser (faeces) was 55\% lower in the dry season than in the rainy season. The proportion of collected faeces on farm was $14 \%$ lower in the dry season than in the rainy season. The proportion of faeces being collected had an important impact on the estimated direct and indirect $\mathrm{N}_{2} \mathrm{O}$ emissions related to manure management.

Table 3 shows the GHGEI per kg milk produced, the contribution of different processes, and proportion of the different GHGs in each season. The different processes are enteric fermentation, manure management, forage cultivation, and the cultivation, transport and processing of purchased feeds. The average GHGEI was higher in the rainy (i.e. $1.32 \mathrm{CO}_{2}$-eq $\mathrm{kg}^{-1} \mathrm{FPCM}$ ) than in the dry (i.e. $0.91 \mathrm{~kg} \mathrm{CO}_{2}$-eq kg ${ }^{-1}$ FPCM) season $(P$ value $<0.05)$. This difference between seasons was explained by differences in emissions related to enteric fermentation (being 23\% higher in the rainy season than in the dry season), manure management (being 38\% higher in the rainy season than in the dry season) and forage cultivation (being $80 \%$ higher in the rainy season than in the dry season). The $\mathrm{CH}_{4}$ from enteric fermentation was the major portion of the total sum of GHGs emitted in both seasons. The GHGEI between the four different MMSs did not differ in the rainy and the dry season (Table S3; Supplementary material). Therefore, we do not further distinguish between farms with different MMS in the present study.

Table 4 shows GHGEI per kg milk at each FV in the rainy and the dry season. The mean GHGEI at each FV ranged from 0.84 (FV6) to 1.40 (FV2) $\mathrm{kg} \mathrm{CO}_{2}$-eq $\mathrm{kg}^{-1}$
Table 4 Mean and standard deviation of greenhouse gas emission intensity (GHGEI) per kg of fat-and-protein-corrected-milk (FPCM) at each farm visit (FV) in rainy and dry season

\begin{tabular}{lll}
\hline Season & Farm visit & $\begin{array}{l}\text { GHGEI (kg } \\
\mathrm{CO}_{2} \text {-eq kg } \\
\text { FPCM)* }\end{array}$ \\
\hline Rainy & FV1 & $1.25(0.51)$ \\
& FV2 & $1.40(0.68)$ \\
Dry & FV3 & $1.27(0.51)$ \\
& FV4 & $0.91(0.44)$ \\
& FV5 & $0.89(0.37)$ \\
& FV6 & $0.84(0.37)$ \\
\hline
\end{tabular}

*Values between the brackets present the standard deviation $(n=32)$

FPCM. Within seasons, GHGEI did not differ between FVs. The results of the GHGE calculations per unit of meat can be found in the Supplementary material (Table S4).

\subsection{Comparing GHGEI of milk within seasons}

Figure $2 \mathrm{a}$ and $\mathrm{b}$ illustrate the GHGEI for each of the 32 smallholder farms at all visits in the rainy (a) and the dry season (b). These figures show that the estimates of GHGEI of each farm varied between FVs within seasons. Variation in GHGEI within a farm can be explained by fluctuations in milk yield across FVs, which could be related to the lactation stage of the cows, and fluctuations in DMI, being related to feed availability. The GHGEI of individual farm visits ranged from 0.3 to $4.3 \mathrm{~kg} \mathrm{CO}_{2}$-eq $\mathrm{kg}^{-1}$ FPCM. The highest value was explained by a low milk yield (e.g. end of lactation), and a high DMI (i.e. abundance of feed in the rainy season). The lowest value was explained by a high milk yield (e.g. beginning of lactation), and a low DMI (i.e. lack of feed in the dry
Table 3 Greenhouse gas emission intensity (GHGEI) per $\mathrm{kg}$ of fat-and-protein-corrected milk (FPCM), emissions per process, and contribution per gas per process in the rainy and dry season

\begin{tabular}{|c|c|c|c|c|c|}
\hline \multirow[t]{2}{*}{ Items } & \multicolumn{2}{|c|}{$\mathrm{kg} \mathrm{CO}_{2}$-eq kg ${ }^{-1} \mathrm{FPCM}$} & \multirow[t]{2}{*}{ GHG } & \multicolumn{2}{|c|}{ Contribution (\%) to GHGEI } \\
\hline & Rainy season & Dry season & & Rainy season & Dry season \\
\hline Total GHGEI & $1.32^{\mathrm{a}}(0.39)$ & $0.91^{\mathrm{b}}(0.22)$ & & & \\
\hline \multicolumn{6}{|l|}{ Emissions per process: } \\
\hline Enteric fermentation & $0.70^{\mathrm{a}}(0.20)$ & $0.54^{\mathrm{b}}(0.11)$ & $\mathrm{CH}_{4}$ & 55 & 60 \\
\hline \multirow[t]{2}{*}{ Manure management } & $0.19^{\mathrm{a}}(0.16)$ & $0.12^{\mathrm{b}}(0.12)$ & $\mathrm{CH}_{4}$ & 10 & 8 \\
\hline & & & $\mathrm{N}_{2} \mathrm{O}$ & 5 & 5 \\
\hline \multirow[t]{2}{*}{ Forage cultivation } & $0.19^{\mathrm{a}}(0.19)$ & $0.05^{\mathrm{b}}(0.12)$ & $\mathrm{N}_{2} \mathrm{O}$ & 13 & 5 \\
\hline & & & $\mathrm{CO}_{2}$ & 1 & 0 \\
\hline \multirow[t]{3}{*}{ Purchased feeds } & $0.22(0.12)$ & $0.20(0.08)$ & $\mathrm{CO}_{2}$ & 12 & 15 \\
\hline & & & $\mathrm{N}_{2} \mathrm{O}$ & 1 & 2 \\
\hline & & & $\mathrm{CH}_{4}$ & 3 & 5 \\
\hline
\end{tabular}

*Values between brackets present the standard deviation $(n=32)$; superscripts show significant difference $(P$ value $<0.05)$ 
(a)

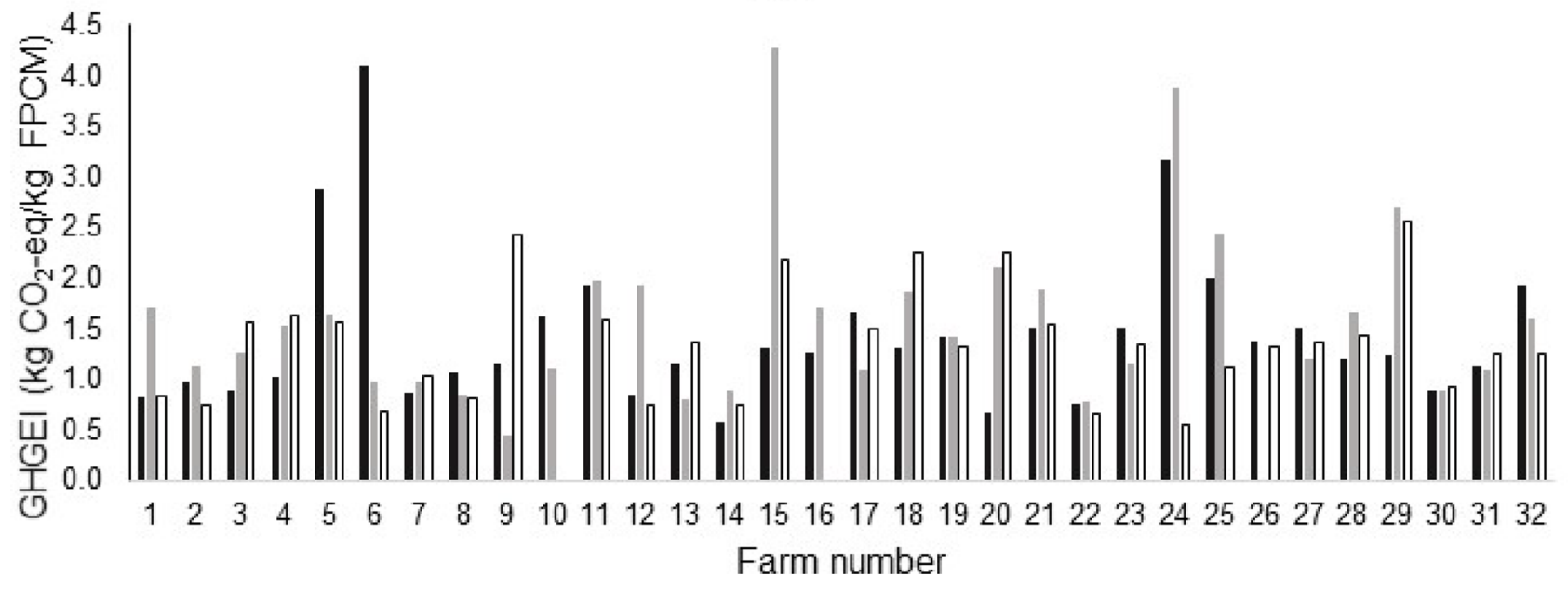

aV1 $\square \mathrm{FV} 2 \square \mathrm{FV} 3$

(b)

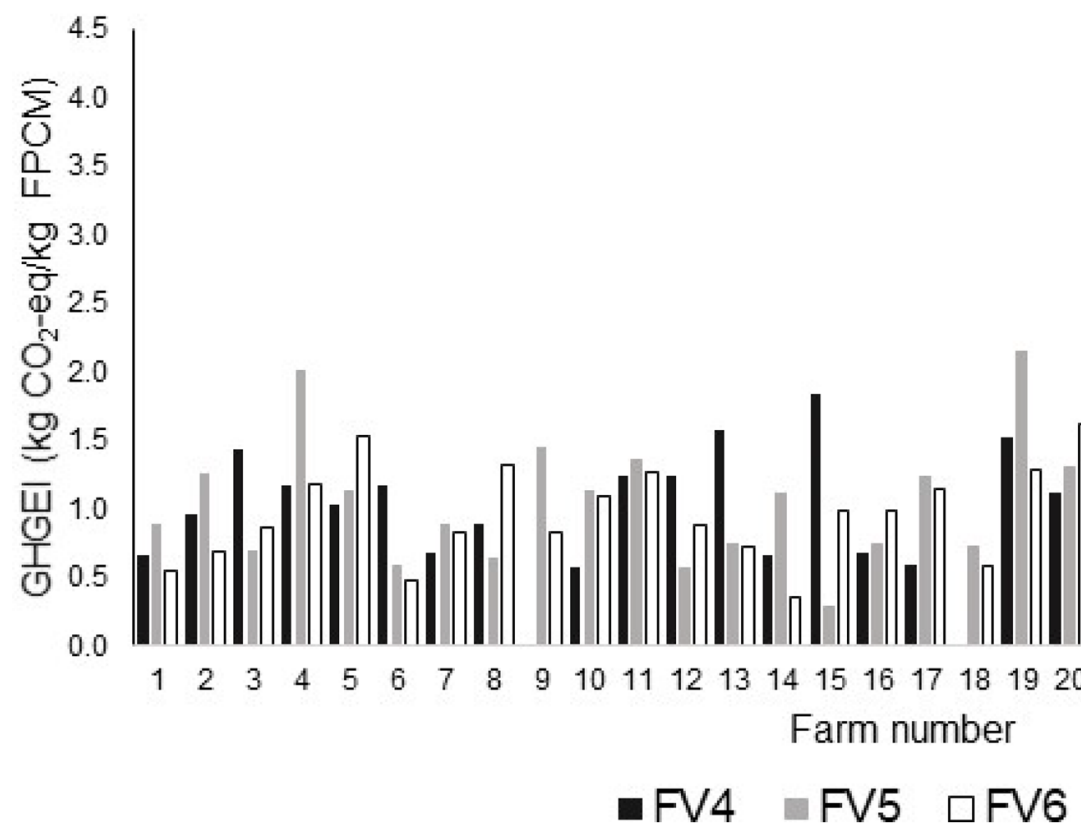

Fig. 2 Greenhouse gas emission intensity (GHGEI; $\mathrm{kg} \mathrm{CO}_{2}$-eq kg ${ }^{-1} \mathrm{FPCM}$ ) for each of the 32 smallholder farms in the rainy season (a) and the dry season (b)

season). In addition to stage of lactation, milk yield is also related to the parity of a cow (i.e. first, second). Since information about parity was based on farmers' interview, it was regarded to be uncertain. The missing data of GHGEI (Fig. 2) relates to a situation where milk yield was zero because cows were in their dry period.

\subsection{Relation between number of farm visits and variability of GHGEI estimate}

Table 5 shows the between farm variance and the within farm variance of the estimated GHGEI for a single farm mean and for the population mean (32 farms), in the rainy 
Table 5 The between farm variance and the within farm variance of the estimated greenhouse gas emission intensity (GHGEI) per $\mathrm{kg}$ of fat-and-protein-corrected-milk (FPCM) for a single farm mean and for the population mean in the rainy and dry season with a sampling scheme of $1,2,3$ or 26 visits per farm

\begin{tabular}{|c|c|c|c|c|}
\hline \multirow[t]{2}{*}{ Between farm variance $\left(\mathrm{kg} \mathrm{CO}_{2}\right.$-eq kg $\left.{ }^{-1} \mathrm{FPCM}\right)$} & \multicolumn{4}{|c|}{ Within farm variance $\left(\mathrm{kg} \mathrm{CO}_{2}-\mathrm{eq} \mathrm{kg}^{-1} \mathrm{FPCM}\right)$} \\
\hline & & $\begin{array}{l}\text { Number } \\
\text { of visits }\end{array}$ & Rainy season & Dry season \\
\hline \multirow[t]{8}{*}{0.025} & \multirow{4}{*}{$\begin{array}{l}\text { Of the esti- } \\
\text { mate for a } \\
\text { single farm } \\
\text { mean }\end{array}$} & 1 & 0.69 & 0.32 \\
\hline & & 2 & 0.34 & 0.16 \\
\hline & & 3 & 0.23 & 0.10 \\
\hline & & $26^{*}$ & 0.027 & 0.012 \\
\hline & \multirow{4}{*}{$\begin{array}{l}\text { Of the esti- } \\
\text { mate for the } \\
\text { population } \\
\text { mean }\end{array}$} & 1 & 0.02 & 0.01 \\
\hline & & 2 & 0.01 & 0.05 \\
\hline & & 3 & 0.008 & 0.004 \\
\hline & & $26^{*}$ & 0.002 & 0.001 \\
\hline
\end{tabular}

*Hypothetical number of visits per farm and dry season based on 1, 2 or 3 visits per farm, and based on a hypothetical number of 26 (i.e. weekly) visits. The between farm variance was $0.025 \mathrm{~kg} \mathrm{CO}_{2}$-eq kg ${ }^{-1}$ FPCM in both seasons. The within farm variance of the estimate for a single farm mean and for the population mean decreased with an increased number of visits per farm in both seasons. In the rainy season, the within farm variance of the estimate for a single farm mean decreased from $0.69 \mathrm{~kg} \mathrm{CO}_{2}$-eq kg $\mathrm{kg}^{-1}$ FPCM (1 visit) to $0.34 \mathrm{~kg} \mathrm{CO}_{2}-\mathrm{eq} \mathrm{kg}^{-1}$ FPCM (2 visits), to $0.23 \mathrm{~kg} \mathrm{CO}_{2}$-eq kg ${ }^{-1} \mathrm{FPCM}$ (3 visits) and to $0.027 \mathrm{~kg}$ $\mathrm{CO}_{2}$-eq kg ${ }^{-1}$ FPCM (26 visits). In the dry season, the within farm variance decreased from $0.32 \mathrm{~kg} \mathrm{CO}_{2}$-eq kg ${ }^{-1} \mathrm{FPCM}$ (1 visit) to $0.16 \mathrm{~kg} \mathrm{CO}_{2}$-eq kg ${ }^{-1} \mathrm{FPCM}$ (2 visits), to $0.10 \mathrm{~kg}$ $\mathrm{CO}_{2}$-eq kg ${ }^{-1}$ FPCM (3 visits), and to $0.012 \mathrm{~kg} \mathrm{CO}_{2}$-eq kg $\mathrm{kg}^{-1}$ FPCM (26 visits). As a result of a decrease in the within farm variance, the width of the $95 \% \mathrm{CI}$ in the estimate for a single farm mean became narrower with an increase in the number of visits (Table 6). The width of the CI decreased from $3.25 \mathrm{~kg} \mathrm{CO}_{2}$-eq kg ${ }^{-1}$ FPCM (1 visit) to $0.64 \mathrm{~kg} \mathrm{CO}_{2}$-eq $\mathrm{kg}^{-1}$ FPCM (26 visits) in the rainy season, and from $2.21 \mathrm{~kg}$ $\mathrm{CO}_{2}$-eq kg ${ }^{-1}$ FPCM (1 visit) to $0.43 \mathrm{~kg} \mathrm{CO}_{2}$-eq kg ${ }^{-1}$ FPCM (26 visits) in the dry season. The repeatability per farm increased when more farm visits were performed (Table 6).
In the rainy season, the within farm variance in the estimate for the population mean decreased from $0.02 \mathrm{~kg}$ $\mathrm{CO}_{2}$-eq kg ${ }^{-1}$ FPCM (1 visit) to $0.01 \mathrm{~kg} \mathrm{CO}_{2}$-eq kg ${ }^{-1}$ FPCM (2 visits), to $0.008 \mathrm{~kg} \mathrm{CO}_{2}$-eq kg ${ }^{-1} \mathrm{FPCM}$ (3 visits) and to $0.002 \mathrm{~kg} \mathrm{CO}_{2}$-eq kg ${ }^{-1} \mathrm{FPCM}$ in case of 26 visits. In the dry season, the within farm variance decreased from $0.01 \mathrm{~kg}$ $\mathrm{CO}_{2}$-eq kg ${ }^{-1}$ FPCM (1 visit) to $0.005 \mathrm{~kg} \mathrm{CO}_{2}$-eq kg ${ }^{-1}$ FPCM (2 visits), to $0.004 \mathrm{~kg} \mathrm{CO}_{2}$-eq kg ${ }^{-1}$ FPCM (3 visits) and to $0.001 \mathrm{~kg} \mathrm{CO}_{2}$-eq kg-1 FPCM (26 visits). As a result of a decrease in the within farm variance, the width of the $95 \%$ $\mathrm{CI}$ in the estimate for the population mean became narrower with an increase in the number of visits (Table 6). The width of the $95 \% \mathrm{CI}$ decreased from $0.58 \mathrm{~kg} \mathrm{CO}_{2}-\mathrm{eq} \mathrm{kg}^{-1} \mathrm{FPCM}$ (1 visit) to $0.16 \mathrm{~kg} \mathrm{CO}_{2}$-eq kg ${ }^{-1}$ FPCM (26 visits) in the rainy season, and from $0.40 \mathrm{~kg} \mathrm{CO}_{2}$-eq kg ${ }^{-1} \mathrm{FPCM}$ (1 visit) to $0.13 \mathrm{~kg} \mathrm{CO}_{2}$-eq $\mathrm{kg}^{-1}$ FPCM (26 visits) in the dry season.

Table 7 shows the between farm variance and within farm variance of the estimated GHGE per process, of the estimate for a single farm mean and for the population mean in the rainy and dry season based on 1, 2, 3 or 26 visits per farm. Forage cultivation has the highest between farm variance, followed by manure management, enteric fermentation and purchased feed. In both seasons, enteric fermentation has
Table 6 Width of the $95 \%$ confidence interval (CI) and repeatability of the estimated greenhouse gas emission intensity (GHGEI) per $\mathrm{kg}$ of fat-and-protein-corrected-milk (FPCM) for a single farm mean and for the population mean in the rainy and dry season with a sampling scheme of $1,2,3$ or 26 visits per farm

\begin{tabular}{|c|c|c|c|c|c|c|}
\hline \multirow{2}{*}{$\begin{array}{l}\text { Number } \\
\text { of visits }\end{array}$} & \multicolumn{3}{|l|}{ Rainy season } & \multicolumn{3}{|l|}{ Dry season } \\
\hline & $\begin{array}{l}\text { Width of CI of the esti- } \\
\text { mate for a single farm } \\
\text { mean }\end{array}$ & $\begin{array}{l}\text { Width of CI of the esti- } \\
\text { mate for the population } \\
\text { mean }\end{array}$ & Repeatability & $\begin{array}{l}\text { Width of CI the esti- } \\
\text { mate for a single farm } \\
\text { mean }\end{array}$ & $\begin{array}{l}\text { Width of CI of the esti- } \\
\text { mate for the population } \\
\text { mean }\end{array}$ & Repeatability \\
\hline 1 & 3.25 & 0.58 & 0.03 & 2.21 & 0.40 & 0.07 \\
\hline 2 & 2.30 & 0.42 & 0.07 & 1.56 & 0.29 & 0.14 \\
\hline 3 & 1.87 & 0.35 & 0.10 & 1.28 & 0.25 & 0.19 \\
\hline $26^{*}$ & 0.64 & 0.16 & 0.49 & 0.43 & 0.13 & 0.67 \\
\hline
\end{tabular}

*Hypothetical number of visits per farm 
Table 7 The between farm variance and within farm variance of the estimated greenhouse gas emissions per $\mathrm{kg}$ of fat-and-proteincorrected-milk (FPCM) per process for a single farm mean and for the population mean in the rainy and dry season with a sampling scheme of $1,2,3$ or 26 visits per farm

\begin{tabular}{|c|c|c|c|c|c|c|}
\hline \multirow[t]{3}{*}{ Process } & \multirow{3}{*}{$\begin{array}{l}\text { Between farm variance }(\mathrm{kg} \\
\left.\mathrm{CO}_{2} \text {-eq kg }{ }^{-1} \mathrm{FPCM}\right)\end{array}$} & \multicolumn{5}{|c|}{ Within farm variance $\left(\mathrm{kg} \mathrm{CO}_{2}\right.$-eq kg $\left.{ }^{-1} \mathrm{FPCM}\right)$} \\
\hline & & \multirow[t]{2}{*}{$\begin{array}{l}\text { Number of } \\
\text { visits }\end{array}$} & \multicolumn{2}{|c|}{$\begin{array}{l}\text { Of the estimate for a single farm } \\
\text { mean }\end{array}$} & \multicolumn{2}{|c|}{$\begin{array}{l}\text { Of the estimate for the popula- } \\
\text { tion mean }\end{array}$} \\
\hline & & & Rainy season & Dry season & Rainy season & Dry season \\
\hline \multirow[t]{4}{*}{ Enteric fermentation } & \multirow[t]{4}{*}{0.007} & 1 & 0.18 & 0.09 & 0.005 & 0.003 \\
\hline & & 2 & 0.09 & 0.04 & 0.003 & 0.002 \\
\hline & & 3 & 0.06 & 0.03 & 0.002 & 0.001 \\
\hline & & $26^{*}$ & 0.007 & 0.003 & 0.0004 & 0.0003 \\
\hline \multirow[t]{4}{*}{ Manure management } & \multirow[t]{4}{*}{0.012} & 1 & 0.036 & 0.016 & 0.002 & 0.0008 \\
\hline & & 2 & 0.018 & 0.008 & 0.0009 & 0.0006 \\
\hline & & 3 & 0.012 & 0.005 & 0.0007 & 0.0005 \\
\hline & & $26^{*}$ & 0.0014 & 0.0006 & 0.0004 & 0.0004 \\
\hline \multirow[t]{4}{*}{ Purchased feeds } & \multirow[t]{4}{*}{0.002} & 1 & 0.008 & 0.004 & 0.0003 & 0.0002 \\
\hline & & 2 & 0.004 & 0.002 & 0.00018 & 0.00012 \\
\hline & & 3 & 0.002 & 0.001 & 0.00015 & 0.00010 \\
\hline & & $26^{*}$ & 0.0003 & 0.0002 & 0.00007 & 0.00007 \\
\hline \multirow[t]{4}{*}{ Forage cultivation } & \multirow[t]{4}{*}{0.017} & 1 & 0.093 & 0.023 & 0.0034 & 0.0012 \\
\hline & & 2 & 0.046 & 0.011 & 0.0019 & 0.0008 \\
\hline & & 3 & 0.031 & 0.007 & 0.0015 & 0.0007 \\
\hline & & $26^{*}$ & 0.004 & 0.0009 & 0.0006 & 0.0006 \\
\hline
\end{tabular}

*Hypothetical number of visits per farm

the highest within farm variance, both for the estimate for a single farm mean and for the population mean, followed by forage cultivation, manure management and purchased feed. For all processes, the within farm variance in the rainy season was higher than in the dry season. In both seasons, the within farm variance of the estimate for a single farm mean and for the population mean decreased with an increase in number of visits per farm.

Table 8 shows the width of the $95 \% \mathrm{CI}$ and repeatability of the estimated GHGE per process in the rainy and dry season with a sampling scheme of $1,2,3$ or 26 visits per farm. The CI is directly related to the within farm variance and, as a result, the width of the CI of the estimate for a single farm mean and for the population mean is largest for enteric fermentation, followed by forage cultivation, manure management, and purchased feed, in both seasons. Repeatability is associated with the between farm variance and the within farm variance. Repeatability of enteric fermentation was the smallest compared to other processes followed by forage cultivation, purchased feed, and manure management in the rainy season. In the dry season, repeatability of enteric fermentation was the smallest compared to other processes followed by purchased feed, forage cultivation, and manure management. Repeatability of all processes were categorised as low and became higher when more farm visits were performed.

\subsection{Comparing GHGEI based on economic allocation and system division}

The economic allocation factor for milk in the rainy season was 0.79 and 0.74 in the dry season. Based on system division, a fraction of 0.82 of total farm emissions were related to adult cows (lactating and dry cows) in both seasons. The average GHGEI based on economic allocation was $1.32 \mathrm{~kg}$ $\mathrm{CO}_{2}$-eq kg ${ }^{-1}$ FPCM in the rainy season and $0.91 \mathrm{~kg} \mathrm{CO}_{2}$-eq $\mathrm{kg}^{-1}$ FPCM in the dry season (Table 3). The average GHGEI based on system division was $1.37 \mathrm{~kg} \mathrm{CO}_{2}$-eq kg ${ }^{-1} \mathrm{FPCM}$ in the rainy season and $1.05 \mathrm{~kg} \mathrm{CO}_{2}$-eq kg${ }^{-1} \mathrm{FPCM}$ in the dry season. The correlation between the average GHGEI of milk per farm per season based on economic allocation and the average GHGEI of milk per farm per season based on system division was strong (i.e. $r=0.85$ in the rainy season, $r=0.90$ in the dry season; Fig. $3 \mathrm{a}, \mathrm{b}$ ).

\section{Discussion}

\subsection{Seasonal GHGE from smallholder dairy farms}

The average GHGEI of milk from all farm visits in our study (1.19 $\mathrm{kg} \mathrm{CO}_{2}$-eq kg ${ }^{-1} \mathrm{FPCM}$ ) was lower than results of the previous studies in the same region of West Java (Taufiq 
Table 8 Width of the 95\% confidence interval (CI) and repeatability of the estimated greenhouse gas emissions per kg fat-and-protein-corrected milk (FPCM) per process in the rainy and dry season with a sampling scheme of 1, 2, 3 or 26 visits per farm

\begin{tabular}{|c|c|c|c|c|c|c|c|}
\hline \multirow[t]{2}{*}{ Process } & \multirow{2}{*}{$\begin{array}{l}\text { Number } \\
\text { of visits }\end{array}$} & \multicolumn{4}{|l|}{ Rainy season } & \multicolumn{2}{|l|}{ Dry season } \\
\hline & & $\begin{array}{l}\text { Width of CI of } \\
\text { the estimate for a } \\
\text { single farm mean }\end{array}$ & $\begin{array}{l}\text { Width of CI of the } \\
\text { estimate for the } \\
\text { population mean }\end{array}$ & Repeatability & $\begin{array}{l}\text { Width of CI of } \\
\text { the estimate for a } \\
\text { single farm mean }\end{array}$ & $\begin{array}{l}\text { Width of CI of the } \\
\text { estimate for the } \\
\text { population mean }\end{array}$ & Repeatability \\
\hline \multirow{4}{*}{$\begin{array}{l}\text { Enteric fermenta- } \\
\text { tion }\end{array}$} & 1 & 1.66 & 0.29 & 0.04 & 1.17 & 0.21 & 0.07 \\
\hline & 2 & 1.17 & 0.21 & 0.07 & 0.83 & 0.15 & 0.13 \\
\hline & 3 & 0.96 & 0.17 & 0.10 & 0.67 & 0.13 & 0.19 \\
\hline & $26^{*}$ & 0.32 & 0.082 & 0.50 & 0.23 & 0.07 & 0.67 \\
\hline \multirow{4}{*}{$\begin{array}{l}\text { Manure manage- } \\
\text { ment }\end{array}$} & 1 & 0.74 & 0.15 & 0.25 & 0.49 & 0.11 & 0.43 \\
\hline & 2 & 0.52 & 0.12 & 0.40 & 0.35 & 0.098 & 0.60 \\
\hline & 3 & 0.42 & 0.10 & 0.50 & 0.28 & 0.091 & 0.69 \\
\hline & $26^{*}$ & 0.14 & 0.08 & 0.90 & 0.09 & 0.07 & 0.95 \\
\hline \multirow[t]{4}{*}{ Purchased feed } & 1 & 0.35 & 0.07 & 0.20 & 0.24 & 0.05 & 0.33 \\
\hline & 2 & 0.24 & 0.05 & 0.33 & 0.17 & 0.04 & 0.50 \\
\hline & 3 & 0.20 & 0.04 & 0.43 & 0.14 & 0.04 & 0.60 \\
\hline & $26^{*}$ & 0.06 & 0.03 & 0.87 & 0.05 & 0.03 & 0.93 \\
\hline \multirow[t]{4}{*}{ Forage cultivation } & 1 & 1.19 & 0.22 & 0.15 & 0.59 & 0.13 & 0.43 \\
\hline & 2 & 0.84 & 0.17 & 0.27 & 0.42 & 0.11 & 0.60 \\
\hline & 3 & 0.69 & 0.15 & 0.35 & 0.34 & 0.10 & 0.69 \\
\hline & $26^{*}$ & 0.23 & 0.09 & 0.83 & 0.11 & 0.09 & 0.95 \\
\hline
\end{tabular}

*Hypothetical number of visits per farm

et al. 2016; De Vries et al. 2019) and in other tropical countries (Wilkes et al. 2020). The difference is mainly explained by the higher average daily milk yield in our study $(14 \mathrm{~kg} /$ cow in dry season, and $15 \mathrm{~kg} / \mathrm{cow}$ in the rainy season) than the studies of De Vries et al. (2019) (12 kg/cow) and Taufiq et al. (2016) (10 kg/cow).

The GHGEI was lower in the dry than in the rainy season, mainly because differences in emissions from enteric fermentation, being associated with dietary composition and a lower DMI. In this study, the farmers increased the fraction of rice straw, concentrate, and tofu by-product in the diet during the dry season to compensate for the low availability of elephant grass. Consequently, feed digestibility was improved, as indicated by the higher ratio of metabolisable energy to gross energy (ME/GE), reducing emissions from enteric fermentation. No significant difference in dietary protein content and milk yield was found between the rainy and the dry season. These findings suggest that altering the diet for lactating cows could potentially reduce GHGE. Changing to a diet with a reduced proportion of fibre, however, potentially increases the risk for acidosis in dairy cattle in the long term if fibre content becomes too low, and health aspects need to be considered (Lean et al. 2008). Although not accounted for in this study, it should furthermore be acknowledged that feeding crop residues such as rice straw and by-products, including the concentrate ingredients used in this study, to dairy cattle, can contribute to avoiding GHGE from straw burning in the rice field and prevention of food waste (Soam et al. 2017). However, using feed ingredients that could potentially be used as food, for instance the tofu by-product that was used in this case, could cause food-feed competition and impair overall food security (Van Zanten et al. 2016).

Manure management was another important contributor to GHGE in this study. The emission factors for manure management (i.e. those for discharged faeces and sold faeces) were based on those closest to our situation (i.e. daily spread and liquid/slurry), as emission factor for discharged faeces are not available. Emissions related to manure management were generally lower in the dry season than in the rainy season as farms discharged more manure during the dry season and the emission factor for discharged manure is lower than for the other MMSs. However, we highlight that discharged manure leads to other environmental impacts, such as eutrophication that poses a significant risk to the aquatic ecosystems and groundwater source (Van Es et al. 2006; Amachika et al. 2016). In the rainy season, more manure is collected for use in the bio-digester, leading to higher $\mathrm{CH}_{4}$ emission related to biogas losses. Optimizing the production and use of bioenergy, therefore, can avoid unnecessary losses and reduce GHGE. Furthermore, in relation to forage cultivation, in the rainy season the amount of applied manure is higher than in the dry season. In an attempt to maximise plant growth during high rainfall, however, 
farmers do not reduce the application of inorganic fertiliser, accordingly, generally leading to overfertilisation and higher $\mathrm{N}$ losses, including those in the form of $\mathrm{N}_{2} \mathrm{O}$. Therefore, we suggest the reduction of inorganic fertiliser when farmers apply manure to the forage cultivation area and highlight the importance of precision fertilisation (including better distribution of manure across the field) to reduce GHGE as well as nutrient losses.

We used economic allocation to allocate GHGE between milk and meat, but also explored an alternative method in which we divided the herd into milk-producing animals and meat-producing animals, avoiding the application of allocation. In case of this alternative method, all GHG emissions from adult cows were attributed to milk, and all GHGE from young stock and male cattle were attributed to meat. We explored this alternative method for two reasons. First, the method seems a legitimate option because according to our observations, Indonesian smallholder dairy farms are rather specialised dairy farms that tend to maintain a constant number of adult cows to support the output of milk, being their main source of income, while young stock and male cattle are generally sold to generate additional income, and not kept for replacement. Based on this observation, attributing emissions from adult cows to milk, and from young stock and male cattle to meat, is in line with the principle of LCA to divide the system into sub-processes to avoid allocation. For the female calves that are ultimately kept or bought for replacement, we argue that the method could still hold under the assumption that the mass quantity of the replacement heifer is similar to that of the culled cow at the moment of replacement. The second reason to explore this alternative method is that the data requirements for calculating GHGE related to milk production are reduced to a minimum. All data related to young stock and male cattle, their diet, manure production, growth, and all the emission calculations to it, can be disregarded using this method. Similarly, economic data to calculate allocation factors, being often debated because of their variability in time, are not needed. Exploring this method as an alternative to economic allocation provides additional information to make an informed decision about the data collection procedure in situations of data scarcity, where cost and time constraints often also play a role. In this particular study, the correlation between GHGEI based on economic allocation and GHGEI based on the alternative method, referred to as system division, was found to be high. It was also shown, however, that economic allocation factors differed between seasons $(0.79$ in the dry and 0.74 in the rainy season), while in case of system division a fraction of 0.82 of the total farm emissions were related to milk production in both seasons. Compared to economic allocation, the average GHGEI per kg milk based on system division was almost $4 \%$ higher in the rainy season, and about $15 \%$ higher in the dry season. It was concluded that, although the correlation between methods was high, results based on system division cannot be compared directly to those based on economic allocation. Based on the difference in results between methods, and the fact that young stock and male cattle are generally not kept for replacement, economic allocation might underestimate the GHGEI of milk produced on smallholder farms with a similar structure.

\subsection{Longitudinal observation for LCA}

Our study shows the relation between the number of farm visits and the variability in estimated GHGEI per kg milk produced on smallholder dairy farms in Indonesia. While the variability in GHGEI between farms refers to a systematic difference in emission estimates across farms, the variability in GHGEI within farms refers to differences in emission estimates across visits to the same farm. The between farm variance, therefore, provides information about the GHG reduction potential by implementing management practices of the best performing farms across all farms within the population. The within farm variance of the estimate for a single farm mean describes the variability in GHGEI per kg milk within a farm based on a known distribution (i.e., Gaussian distribution). The within farm variance provides important information to interpret results related to the performance of an individual farm, e.g. compared to that of another farm, or over time. The within farm variance in the estimate for the population mean describes the variability in GHGEI per $\mathrm{kg}$ milk of a specific farm population, in this case of the 32 farms incorporated in this study.

The within farm variance can be reduced by increasing the number of visits per farm (See and Holmes 2015), resulting in a more precise estimate of GHGE of a particular farm, or in a more precise estimate for the population mean. In this study, the within farm variance of the estimate for a single farm mean and the population mean was found to be higher than the between farm variance (i.e. within farm variance $>90 \%$ of the total variance in both seasons). This indicates that the farms in this study are rather homogeneous in terms of their GHGEI per kg milk, and that the main source of variation in GHGEI relates to the within farm variance, i.e. variation in emission estimates across visits to the same farm. Although increasing the number of visits per farm could be a solution to reduce the within farm variance, the required number of replications (visits) to achieve a desired precision is unknown in advance (Adewunmi and Aickelin 2012). The within farm variance of the estimate for the population mean reduces not only with an increase in visits per farm, but also with an increase in the number of farms visited. In our specific case, however, increasing the number of farms would probably not have resulted in a better estimate for the population mean, given the relatively small between farm variance, whereas increasing visits per 
Fig. 3 Relation between greenhouse gas emissions intensity (GHGEI) based on economic allocation and GHGEI based on system division in the rainy (a) and dry season (b). GHGEI is expressed in $\mathrm{kg} \mathrm{CO}_{2}$-equivalents per kg of fat-and proteincorrected-milk $\left(\mathrm{kg} \mathrm{CO}_{2}\right.$-eq kg ${ }^{-1}$ FPCM)

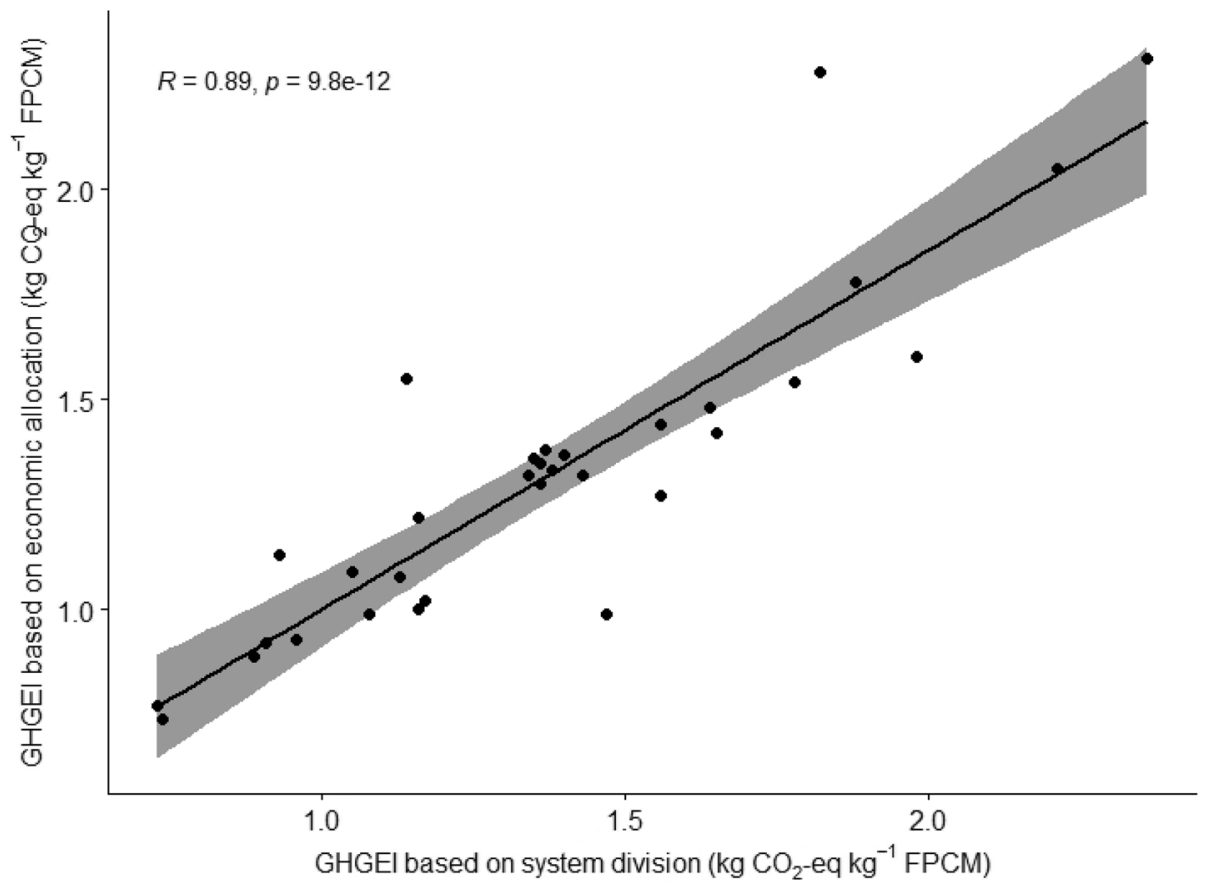

(b)

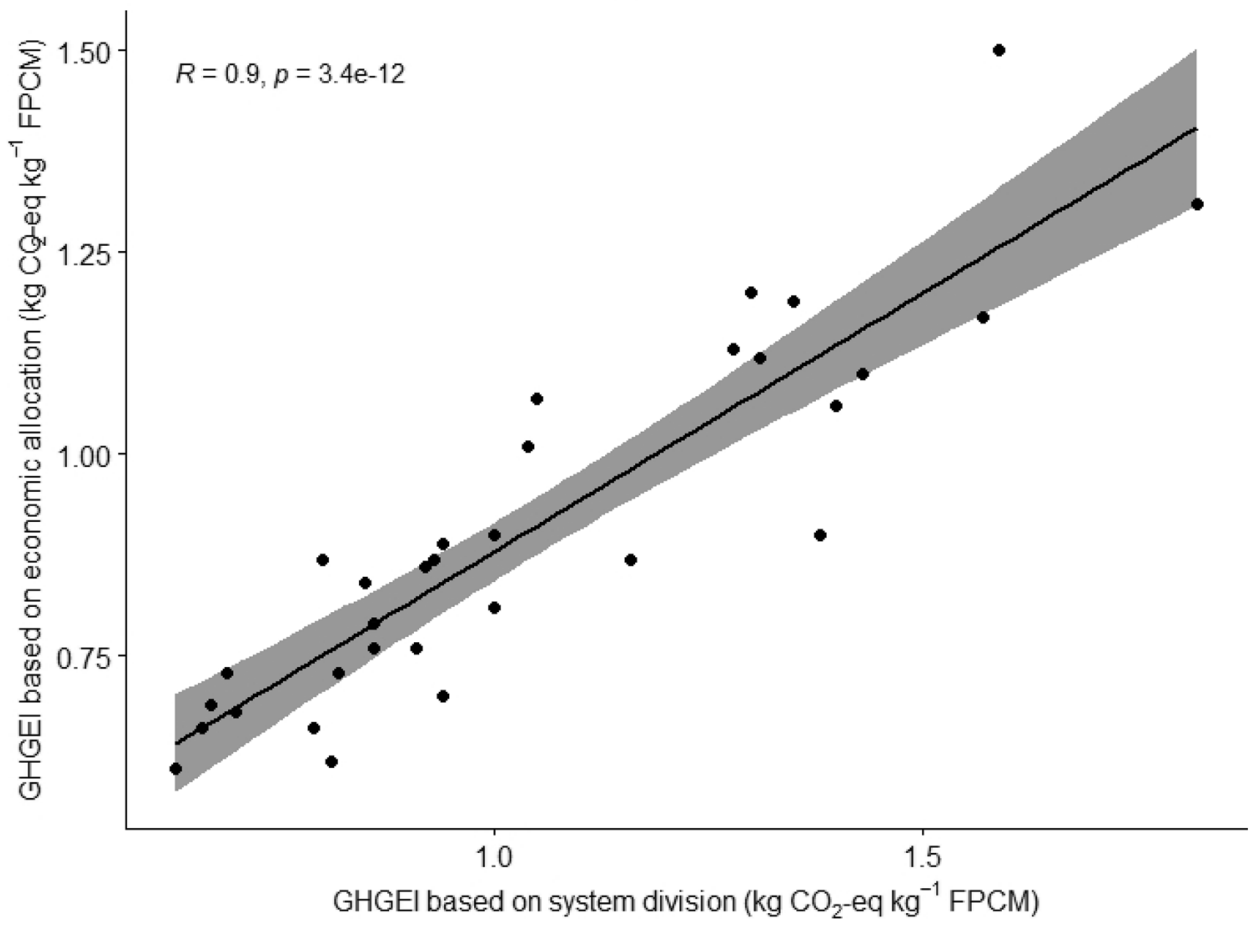

farm would have. This provides an important indication for future studies that aim to assess the GHGEI for a small population of rather homogeneous farms; rather than increasing the number of farms they might aim for increasing the number of visits per farm to improve the accuracy of their assessment. As a last aspect, results indicate a larger need to collect more data in the rainy season than in the dry season, because the within farm variance was higher in the rainy than in the dry season.

The width of the CI is an indicator for the precision in the estimate (Liu 2010). In both seasons, the width of a $95 \%$ CI was narrower when more visits per farm were performed because the standard error decreased due to the increase of $n$. In both seasons, the repeatability within a farm was 
considered low, being related to the high within farm variance. The repeatability increased based on a hypothetical number of 26 visits per farm, from low to moderate, because the increase of $n$ reduces the within farm variance.

We investigated the variation in GHGE per process, in relation to its contribution to the GHGEI of milk. Forage cultivation was found to have the largest between farm variance in estimated GHGE among the four processes (Table 7). Potential explanations for this relatively large variation are systematic differences in the type and amount (i.e. land area and yield) of on-farm produced feed per kg milk, and in the quantity of fertilisers applied including urea, faeces and digestate. The between farm variance in GHGE from manure management can potentially be explained by either variability in the estimated amount of collected manure between farms with the same MMS, or by differences in MMS between farms. Comparing GHGEI between farms with different MMS, however, did not show a significant effect of MMS. This lack of statistical difference is likely related to the fact that most of the farms, regardless their MMS, discharge (part of) their manure, and emissions from discharged manure were calculated based on the same emission factor as the one that was used for applied manure for forage cultivation. The within farm variation in GHGE from manure management is therefore larger than the between farm variation. Furthermore, as the data about forage cultivation and manure management were obtained via interviews, variation in the estimated GHGE might also be explained by systematic differences in farmers' estimates. The between farm variance of estimated GHGE from enteric fermentation indicates that there is no clear systematic difference in feeding strategy between farms, that, based on the calculation method used, affects the level of enteric $\mathrm{CH}_{4}$ per kg milk. Of all processes, purchased feed was found to have the lowest between farm variance.

In case of within farm variance of the estimated GHGE per process, enteric fermentation was found to have the largest variance among the four processes. The variation could be explained by changes in diet composition over time, being related to the availability of forage across the year. In addition, enteric fermentation is the largest contributor to the GHGEI of milk, and any change in this parameter will have a significance effect on the GHGEI. As a result of the relatively large within farms variance, the width of the CI was wider, and the repeatability was lower for enteric fermentation than for other processes. For all processes, the within farm variance of the estimated GHGE of the estimate for a single farm mean and for the population mean was higher in the rainy than in the dry season.

Overall, this study shows the relation between the number of visits per farm and the variances of the estimated GHGEI of milk produced on smallholder dairy farms in Indonesia. Dependent on the objective of the study, i.e. estimating emissions of an individual farm or of a population of rather homogenous farms, such information can help to make a well-informed choice on the data collection procedure, being often constraint by money and time issues. We observed that weekly data collection (i.e. a hypothetical number of 26 visits per season) could improve the accuracy of the estimated GHGEI immensely, which underlines the importance of an intensive recording system to collect data at smallholder dairy farms to improve the accuracy of GHGE estimates.

\section{Conclusions}

The estimated GHGEI of milk produced by smallholders in Lembang district, Indonesia, was higher in the rainy season than in the dry season. The lower GHGEI in the dry season was explained by differences in dietary composition for lactating cows, resulting in lower enteric $\mathrm{CH}_{4}$ emissions, and differences in manure management practices, including applied manure for forage cultivation. The primary source of variation of the estimated GHGEI per kg milk relates to within farms variability, which can be reduced by increasing the number of farm visits. Performing multiple visits, therefore, reduces the within farm variance of the GHGE estimate, reduces the width of the confidence interval, and increases the repeatability per farm. Looking at the individual processes, this study showed that the estimated GHGE from forage cultivation was the main source of variability between farms, whereas the estimated GHGE from enteric fermentation was the main source of variability within farms. Insight into the relation between the number of visits per farm and the variance of the GHGE estimate can help to make a well-informed decision on the data collection procedure. Implementing an intensive recording system to collect data at smallholder dairy farms would improve the accuracy of GHGE estimates significantly.

Supplementary Information The online version contains supplementary material available at https://doi.org/10.1007/s11367-021-01923-z.

Acknowledgements The Indonesian Endowment Fund for Education (LPDP) is acknowledged for a doctoral scholarship to the first author (Windi Al Zahra). The dairy cooperative/Koperasi Peternakan Sapi Perah Bandung Utara (KPSBU) Jawa Barat Indonesia is acknowledged for supporting data collection. This work was implemented as part of the CGIAR Research Program on Climate Change, Agriculture and Food Security (CCAFS) with funding support from the government of The Netherlands. CCAFS is carried out with support from CGIAR Fund Donors and through bilateral funding agreements. For details, please visit https://ccafs.cgiar.org/donors. The views expressed in this document cannot be taken to reflect the official opinions of these organisations.

Author contribution Conceptualisation, methodology, and writingoriginal draft preparation was performed by Windi Al Zahra and Titis Apdini. Formal analysis and investigation, writing - review and editing, and supervision was performed by Simon J. Oosting, Imke J.M. de Boer, Corina E. van Middelaar, Marion de Vries. Statistical analysis was performed by Bas Engel. 


\section{Declarations}

Conflict of interest The authors declare no competing interests.

Open Access This article is licensed under a Creative Commons Attribution 4.0 International License, which permits use, sharing, adaptation, distribution and reproduction in any medium or format, as long as you give appropriate credit to the original author(s) and the source, provide a link to the Creative Commons licence, and indicate if changes were made. The images or other third party material in this article are included in the article's Creative Commons licence, unless indicated otherwise in a credit line to the material. If material is not included in the article's Creative Commons licence and your intended use is not permitted by statutory regulation or exceeds the permitted use, you will need to obtain permission directly from the copyright holder. To view a copy of this licence, visit http://creativecommons.org/licenses/by/4.0/.

\section{References}

Adewunmi A, Aickelin U (2012) Investigating the effectiveness of variance reduction techniques in manufacturing, call center and cross-docking discrete event simulation models. In: Bangsow S. (eds) Use cases of discrete event simulation. Springer, Berlin, Heidelberg. https://doi.org/10.1007/978-3-642-28777-0_1

Agatha RM (2016) Life Cycle Assessment (LCA) untuk rantai pasok agroindustri beras pandanwangi (studi kasus di Kecamatan Cianjur, Jawa Barat). IPB University, Thesis

Amachika Y, Anzai H, Wang L, Oishi K, Irbis C, Li K, Kumagai H, Imanura T, Hirooka H (2016) Estimation of potassium and magnesium flows in animal production in Dianchi Lake basin, China. Anim Sci J 87:938-946. https://doi.org/10.1111/asj.12518

AOAC (1990) Official methods of analyses, 15th edn. Association of Official Analytical Chemist Inc, Washington, USA

BPS. (2018) Statistics of national milk supply. National Bureau of Statistic, Republic of Indonesia. https://www.bps.go.id/indicator/24/493/1/ fresh-milk-production-by-province.html Accessed 5 February 2019

Brooks ME, Kristense K, Van Benthem KJ, Magnussin A, Berg CW, Nielsen A, Skaug HJ, Mächler M, Bolker BM (2017) glmmTMB balances speed and flexibility among packages for zero-inflated generalized linear mozex modelling. The R Journal 9(2):378-400. https://journal.r-project.org/archive/2017/RJ-2017-066/index.html

Cox DR, Hinkley DV (1979) Theoretical Statistics. Chapman \& Hall

De Vries M, Wouters B (2017) Characteristics of small-scale dairy farms in Lembang, West-Java. Wageningen Livestock Research, Report 1076. https://doi.org/10.18174/430110

De Vries M, Al ZW, Wouters A, Van Middelaar CE, Oosting SJ, Tiesnamurti B, Vellinga TV (2019) Entry points for reduction of greenhouse gas emissions in small-scale dairy farms: looking beyond milk yield increase. Front Sustain Food Syst 3:1-13. https://doi.org/10.3389/fsufs.2019.00049

FAO (2015) Global database of GHG emissions related to feed crops. Food and Agriculture Organization of the United Nations. http://www.fao.org/partnerships/leap/database/ghg-crops/en/. Accessed 02 February 2019

FAO, GDP (2018) Climate change and the global dairy cattle sector - The role of the dairy sector in low-carbon future. Food and Agriculture Organization of the United Nations and Global Dairy Platform. http:// www.fao.org/3/CA2929EN/ca2929en.pdf . Accessed 10 March 2019

Garg MR, Phondba BT, Sherasia PL, Makkar HPS (2016) Carbon footprint of milk production under smallholder dairying in Anand district of Western India: a cradle-to-farm gate life cycle assessment. Anim Prod Sci 56:423-436. https://doi.org/10.1071/AN15464
Gerber PJ, Steinfeld H, Henderson B, Mottet A, Opio C, Dijkman J, Falcucci A, \&Tempio, G (2013) Tackling climate change through livestock - A global assessment of emissions and mitigation opportunities. Food and Agriculture Organization of the United Nations (FAO), Rome

IDF (2015) A common carbon footprint approach for the dairy sector: The IDF guide to standard life cycle assessment methodology. International Dairy Federation (IDF). https://store.fil-idf.org/ product/a-common-carbon-footprint-approach-for-the-dairy-sector-the-idf-guide-to-standard-life-cycle-assessment-methodology/ . Accessed 02 December 2018

IPCC (2019) Refinement to the 2006 IPCC Guidelines for National Greenhouse Gas Inventories, Calvo Buendia, E., Tanabe, K., Kranjc, A., Baasansuren, J., Fukuda, M., Ngarize S., Osako, A., Pyrozhenko, Y., Shermanau, P. and Federici, S. (eds). Published: IPCC, Switzerland

IPCC (2006) IPCC Guidelines for National Greenhouse Gas Inventories, Prepared by the National Greenhouse Gas Inventories Programme, Eggleston H.S., Buendia L., Miwa K., Ngara T. and Tanabe K. (eds). Published: IGES, Japan

IRENA (2016) Measuring small-scale biogas capacity and production, International Renewable Energy Agency (IRENA). https://www. irena.org/publications/2016/Dec/Measuring-small-scale-biogascapacity-and-production . Accessed 05 June 2019

Kementan, (2018) Livestock and animal health statistics 2018. Kementerian Pertanian Republik Indonesia, Jakarta

Kemenko Ekon (2016) Coordinating Ministry of Economy, Republic of Indonesia. Reviewing blueprint of national milk production 2017-2025. https://ditjenpkh.pertanian.go.id/pemerintah-reviewcetak-biru-persusuan-tahun-2013-2025Accessed 20 April 2017

KPSBU (2018) Annual report of dairy cooperative in North Bandung. Koperasi Peternak Sapi Perah Bandung Utara, Bandung Barat

Kusuma SB, Ngadiyono N (2017) The correlation of body measurements and weights of Ongole Crossbred (PO) cattle in Kebumen Regency. https://journal.ugm.ac.id/istapproceeding/article/view/ 30043. Accessed 20 September 2019

Lanyasunya TP, Wang HR, Mukisira SA, Abdulrazak SA, Ayako WO (2006) Effect of seasonality on feed availability, quality and herd performance on smallholder farms in Ol-Joro-Orok Location/Nyandarua District, Kenya. Trop Subtrop Agroecosystems 6:87-93. https://www.redalyc.org/articulo.oa?id=939/93960206

Lean IJ, Westwood CT, Playford MC (2008) Livestock disease threats associated with intensification of pastoral dairy farming. $\mathrm{N} \mathrm{Z} \mathrm{Vet}$ J 56:261-269. https://doi.org/10.1080/00480169.2008.36845

Liu XS (2010) Sample size for confidence interval of covariateadjusted mean difference. J Educ Behav Stat 35(6):714-725. https://doi.org/10.3102/1076998610381401

Liu X, Bai Y, Chen J (2017) An intermodal transportation geospatial network modeling for containerized soybean shipping. J Ocean Eng Sci 2:143-153. https://doi.org/10.1016/j.joes.2017.05.001

Maleko D, Ng WT, Msalya G, Mwilawa A, Pasape L, Mtei K (2018) Seasonal variations in the availability of fodder resources and practices of dairy cattle feeding among the smallholder farmers in Western Usambara Highlands, Tanzania. Trop Anim Health Prod 50:1653-1664. https://doi.org/10.1007/s11250-018-1609-4

McCulloch CE, Searle SR, Neuhaus JM (2008) Generalized, Linear, and Mixed Models, 2nd edn. John Wiley

Migose SA, van der Linden A, Bebe BO, de Boer IJ, Oosting SJ (2020) Accuracy of estimates of milk production per lactation from limited test-day and recall data collected at smallholder dairy farms. Livest Sci 232. https://doi.org/10.1016/j.livsci.2019.103911

Morey P (2011) Indonesia dairy industry development. International Finance Corporation - World Bank Group. https://www.semanticscholar.org/ paper/Dairy-industry-development-in-Indonesia-Final-May-Morey/ f23240ce348ab143alc7f3fe261a29fff6ca861f Accessed 17 March 2019 
Myhre G, Shindell D, Bréon FM, Collins W, Fuglestvedt J, Huang J, Koch D, Lamarque JF, Lee D, Mendoza B, Nakajima T, Robock A, Stephens G, Takemura T, Zhang H (2013) Anthropogenic and natural radiative forcing. In: Climate Change 2. Cambridge University Press, Cambridge, United Kingdom and New York, NY, USA. Park, S., 2018. Factors influencing

NRC (2001) Nutrient requirement of dairy cattle, 7th edn. National Academy Press, Washington, D. C.

Paul S, Onduru D, Wouters B, Gachimbi L, Zake J, Ebanyat P, Ergano K, Abduke M, Van Keulen H (2009) Cattle manure management in East Africa: review of manure quality and nutrient losses and scenarios for cattle and manure management. Wageningen Livest Res, Report 258. https://edepot.wur.nl/12191

Priyanti A, Soedjana TD (2015) Indonesian Dairy Industry Perspective Within the ASEAN Economic Community. Wartazoa 25:159170. https://doi.org/10.14334/wartazoa.v25i4.1226

Richards S, VanLeeuwen J, Shepelo G, Gitau GK, Kamunde C, Uehlinger F, Wichtel J (2015) Associations of farm management practices with annual milk sales on smallholder dairy farms in Kenya. Vet World 8:88-96. https://doi.org/10.14202/vetworld. 2015.88-96

See KE, Holmes EE (2015) Reducing bias and improving precision in species extension forecast. Ecol Soc Am 25(4):1157-1165. https:// doi.org/10.1890/14-2003.1

Soam S, Borjesson P, Sharma PK, Rp G, Tuli DK, Kumar R (2017) Life cycle assessment of rice straw utilization practices in India. Bioresour Technol 228:89-98. https://doi.org/10.1016/j.biortech. 2016.12.082

Suroso E (2011) Model proses produksi industri tapioka ramah lingkungan berbasis produksi bersih (studi kasus di Provinsi Lampung). Dissertation, IPB University

Taufiq FM, Padmi T, Rahardyan B (2016) Life cycle assessment of dairy farms. Rev Environ Health 31:187-190. https://doi.org/10. 1515/reveh-2015-0037

Tubiello FN, Salvatore M, Cóndor Golec RD, Ferrara A, Rossi S, Biancalani R, Federici S, Jacobs H, Flammini A (2014) Agriculture, Forestry and Other Land Use Emissions by Sources and Removals by Sinks. Food and Agriculture Organization of United Nations (FAO). http://www.fao. org/publications/card/en/c/cf02ec83-b364-57ae-bcff-cc285d1d4b1a. Accessed 09 January 2019

Van Es HM, Sogbedji JM, Schindelbeck RR (2006) Effect of manure application timing, crop, and soil type on nitrate leaching. J Environ Qual 35:670-679. https://doi.org/10.2134/jeq2005.0143

Van Zanten HHE, Meerburg BG, Bikker P, Herrero M, De Boer IJM (2016) Opinion paper: The role of livestock in a sustainable diet: a land-use perspective. Animal 10:547-549. https://doi.org/10. $1017 /$ S1751731115002694

Vellinga TV, Blonk H, Marinussen M, Van Zeist WJ, De Boer IJM, Starmans D (2013) Methodology used in FeedPrint: a tool quantifying greenhouse gas emissions of feed production and utilization. Wageningen UR Livestock Research. https://edepot.wur.nl/ 254098. Accessed 10 February 2019

Wernet G, Bauer C, Steubing B, Reinhard J, Moreno-Ruiz E, Weidema B (2016) The ecoinvent database version 3 (part I): overview and methodology. Int J Life Cycle Assess 21:1218-1230. https://doi. org/10.1007/s11367-016-1087-8

Wilkes A, Wassie S, Odhong C, Fraval S, Van Dijk S (2020) Variation in the carbon footprint of milk production on smallholder dairy farms in central Kenya. J Clean Prod 26:121780. https://doi.org/ 10.1016/j.jclepro.2020.121780

Zahra WA, Van Middelaar CE, de Boer IJM, Oosting SJ (2020) Predicting nutrient excretion from dairy cows on smallholder farms in Indonesia using readily available farm data. Asian-Australasian J Anim Sci 33:2039-2049. https://doi.org/10.5713/ajas.20.0089

Zake J, Tenywa J, Kabi F (2010) Improvement of manure management for crop production in Central Uganda. J Sustain Agric 34(6):595617. https://doi.org/10.1080/10440046.2010.493368

Zannah N (2017) Kajian peluang penerapan produksi bersih di industri tahu (Studi kasus di industri tahu Bandung Raos Cap Jempol). http://repository.ipb.ac.id/handle/123456789/90062. Accessed 15 November 2018

Publisher's Note Springer Nature remains neutral with regard to jurisdictional claims in published maps and institutional affiliations.

\section{Authors and Affiliations}

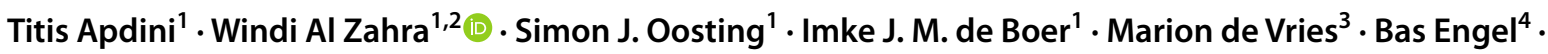 Corina E. van Middelaar ${ }^{1}$}

1 Animal Production Systems Group, Wageningen University \& Research, P.O. Box 338, 6700 AH Wageningen, The Netherlands

2 Department of Animal Production and Technology, Faculty of Animal Science, IPB University (Bogor Agricultural University), P.O Box 16680, Bogor, West Java, Indonesia
3 Wageningen Livestock Research, Wageningen University \& Research, P.O. Box 338, 6700 AH Wageningen, The Netherlands

4 Biometris, Wageningen University \& Research, P.O. Box 100, 6700 AC Wageningen, The Netherlands 